\title{
ROLE OF HARIDRADI TAILAM APPLICATION IN PREVENTION OF NABHI PAKA (UMBILICAL SEPSIS) IN NEONATES
}

Raut D. W.*, Chavan D. B.

Dept. of Kaumarbhritya, Government Ayurved College, Nanded, Maharashtra, India

Received on: 02/01/13 Revised on: 20/02/13 Accepted on: 10/03/13

\author{
*Corresponding author \\ E-mail: rautdeokumar@gmail.com \\ DOI: $10.7897 / 2277-4343.04315$ \\ Published by Moksha Publishing House. Website www.mokshaph.com \\ All rights reserved.
}

\begin{abstract}
Ayurveda is the oldest science of life. The first cut wound which the newborn gets is at birth in Nabhinal paricharya is clearly explained in Charak Samhita. Due to improper Nabhinal paricharya babies are more prone to develop complications like local sepsis, septicemia, tetanus neonatorum, portal vein thrombosis, peritonitis, umbilical hernia, etc. Charaka has mentioned haridradi tailam application after cutting the umbilical cord on umbilical stump in the prevention of nabhipaka. In this study two groups of 30 newborns each irrespective of sex, weight and gestational age were selected randomly. Haridradi tailam was applied to umbilical stump till it completely shaded off. Parameters such as redness, tenderness and swelling at umbilicus, pus discharge through umbilicus were adopted to assess the effect of Haridradi Tailam. At the end of study it was found that Haridradi tailam was very effective in Nabhinal paricharya in the prevention of nabhipaka. It also reduces signs like redness, tenderness and swelling but shown insignificant changes in $\mathrm{C}$-reactive protein.
\end{abstract}

Keywords: Septicemia, Umbilical hernia, C-reactive protein, Gram staining.

\section{INTRODUCTION}

Motherhood nowadays is not simple. It is known very well only by them who want a child. Motherhood is happiest part of the life. Every couple will be prepared to take any type of treatment in order to prevent the diseases of body and mind. Even with all the efforts put forth if not satisfied completely then there will be grief-stricken in their mind. After many difficulties and efforts when birth of the child takes place then there will be feeling of happiness to couples which is infinite. Then it will be more responsible to take care of the baby. Ayurveda has always proved to be efficient and eminent in taking such ailments, since ancient times. Ayurveda is not confined to medicine only it considers whole subject of life in its various ramifications. Ayurveda is considered as the upaveda ${ }^{1}$ or accessory veda to the Atharvaveda. It has eight branches kayachikitsa, Balchikitsa, Grahachikitsa, Shalakyachikitsa, Shalyachikitsa, Vishachikitsa, Rasayanchikitsa, and Vajeekaran chikitsa. ${ }^{2}$

The purpose of life is four fold (chaturvidh purushartha). Every Human being tried to achieve these purusharthas namely Dharma, Artha, kama and Moksha. Health, mind and body are very essential for these various acts, acquirement of wealth, gratification of desire and final emancipation. Achievement of these purusharthas ${ }^{3}$ is fulfilled by healthy life.

In today's fast growing world the human life style is becoming more and more restless on each day. This is because of many factors, like over population, pollution, stress, dietary habits etc. But unnoticed, these factors are taking their toll on the general health population. The basic principle of Ayurveda is prevention and cure. ${ }^{4}$

Throughout the life, everyone has to face different kinds of major and minor cuts and wounds. The first cut wound, which the newborn gets, is at birth i.e. cut of Umbilical cord. If proper care is not taken during the cutting of
Umbilical cord many complications can arise. Therefore cutting and care of cut Umbilical cord has always been a problem.

The cutting and care of Umbilical cord is called as 'Nabhinal paricharya' as mentioned in Charak Samhita which comprises of the preventive measures and care to be taken of the umbilical stump ${ }^{5}$. Nabhinal paricharya is very essential and vital for newborns, as the babies are more prone to develop complications like local sepsis ${ }^{6}$, septicemia, tetanus neonatorum, portal vein thrombosis, peritonitis, Umbilical hernia; exomphalos ${ }^{7,} 8$ also permanent sequlaes like physical and mental deformities may be developed. Hence Nabhinal paricharya must be done with uttermost care.

Maternal and child health programme, tries to reduce these incidences through proper cord care and aseptic precautions. The sequel of improper Nabhinal paricharya are omphalitis, umbilical hernia etc. If the baby suffers from such problems, their parents or family members are under stress because of these complications.

According to Nabhinal paricharya, prepared Haridradi Tailam is used for the local application of Umbilical cord. Though modern system of medicine is very much progressive but its drugs used in Umbilical sepsis in neonate has too much side effects ${ }^{9}$. So to establish the importance of Ayurvedic concepts and remedies related to Nabhipaka, the disease is selected for study. This study is also important in view of enhancing the scope of Ayurvedic treatment, since large numbers of patients suffering from this disease are unsatisfactory with existing management.

It is essential to prevent and to treat the disease with such a remedy which will eliminate the root cause of the disease. Therefore an attempt was made in order to prevent such chronic illness, to prove the efficacy of the 
drugs mentioned in Charak samhita and to prevent the occurrence of Nabhipaka.

\section{Aim}

To prevent the infections and other complications of Umbilicus of the newborn

\section{MATERIALS AND METHOD}

For the Nabhinal paricharya of newborns Haridradi Tailam mentioned in text Charak Samhita is applied on the umbilicus and umbilical cord once daily till the cord sheds ${ }^{10}$.

Table 1: Ingredient of Haridradi Tailam

\begin{tabular}{|c|c|c|c|}
\hline Name & Latin name & Part used & Amount \\
\hline Haridra & Curcuma longa & Rhizome & 1 part \\
\hline Lodhra & Symplocos racemosa & Bark & 1 part \\
\hline Priyangu & Callicarpa macrophylla & Flower & 1 part \\
\hline Devdaru & Cedrus deodara & Bark & 1 part \\
\hline Yestimadhu & Glycerrhiza glabra & Root & 1 part \\
\hline Sesame Oil & Sesamum indicum & Seed oil & 20 part \\
\hline Water & - & - & 80 part \\
\hline
\end{tabular}

\section{Preparation of Haridradi Tailam}

'Haridradi Tailam' is classical oil, indicated in Charak Samhita (an authoritative text) for various disorders of umbilical cord.

\section{Method of preparation}

Haridra, Lodhra, Priyangu, Yesthimadhu and Devdaru were procured from the local market and after cleaning they were finely powdered.

For preparation of Siddha Tailam one part of Kalka of above mentioned drugs, four parts of sesame oil and sixteen parts of water were mixed in wide mouthed vessel. It was heated over low flame till complete evaporation of water. Then it was allowed to cool and filtered $^{11,12}$

\section{Physicochemical Analysis}

Physicochemical Analysis of Haridradi Tailam was performed at drug testing laboratory, Nanded, India and results obtained mentioned below;

Table 2: Results of Physicochemical analysis of Haridradi Tailam

\begin{tabular}{|c|c|}
\hline Test & Result \\
\hline Moisture & $0.10 \%$ \\
\hline Butro refractometer reading at $400^{\circ} \mathrm{C}$ & 60.00 \\
\hline Saponification value & 201.86 \\
\hline Iodine value & 108.19 \\
\hline Unsaponification matter & $0.58 \%$ \\
\hline Acid value & 4.58 \\
\hline
\end{tabular}

\section{Clinical Study}

Before initiation of the study, study protocol and related documents were reviewed and approved by Institutional Ethics Committee (GACN/SS/D-3/123/07 Dated 11/01/2007) at Government Ayurved College, Nanded, Maharashtra, India.

Two groups of 30 Newborns, each irrespective of sex, weight and gestational age were selected randomly.

\section{Experimental group}

Newborns cord was cut by sharp scissor just after first cry about $6 \mathrm{~cm}$ away from the base of umbilicus. Then it was ligated with silk thread and Haridradi Tailam applied on umbilical cord and umbilicus once daily till the cord sheds ${ }^{10}$.

\section{Control group}

Newborns cord was cut by sharp scissor just after first cry and ligated with silk thread about $6 \mathrm{~cm}$ away from the base of umbilicus and surgical sprit applied to the cut cord only once ${ }^{13}$.

\section{Criteria for the selection of volunteers}

- Newborn baby

- Baby free from cardio-respiratory diseases

- Baby free from medical and surgical emergencies.

\section{Criteria for rejection of volunteers}

- Baby born with thick meconium stained liquor.

- Baby with meconium aspiration syndrome.

- Baby having severe birth asphyxia.

- Foul smell vaginal discharge of parturiant

- Baby of febrile parturiant.

- Baby having any serious medical or surgical emergencies.

- Baby having complications during treatment dropped out from study.

\section{Investigations}

- CRP (C-reactive protein) Before and after study ${ }^{14,15}$

- Total Leucocyte Count - Before and after study

- Gram Staining - To rule out the infection and pathogenic organisms [If sepsis or umbilical pus discharge occurred from umbilical cord]

\section{Criteria for Assessment}

Criteria's such as weight, baby temperature, Redness at umbilicus, tenderness at umbilicus, swelling at umbilicus, pus discharge through umbilicus were adopted to assess the effect of Nabhinal paricharya till shedding of umbilical cord. 
Table 3: Classification of Nabhipaka

\begin{tabular}{|c|c|c|c|}
\hline Group & e/o s/o Nabhipaka & No e/o s/o Nabhipaka & Total \\
\hline Trial & $5(16.66 \%)$ & $25(83.33 \%)$ & 30 \\
\hline Control & $17(56.66 \%)$ & $13(43.33 \%)$ & 30 \\
\hline Total & 22 & 38 & 60 \\
\hline \multicolumn{2}{|c|}{$\mathrm{X}^{2}=10.33 ;$ D.F. $=1 ; \mathrm{P}=6.64($ at 0.01$) ; \chi^{2}>\mathrm{P}($ at 0.01$)$}
\end{tabular}

Table 5: Classification of Tenderness at Umbilicus

\begin{tabular}{|c|c|c|c|}
\hline Group & e/o Tenderness & No e/o Tenderness & Total \\
\hline Trial & $1(3.33 \%)$ & $29(96.66 \%)$ & 30 \\
\hline Control & $10(33.33 \%)$ & $0(66.66 \%)$ & 30 \\
\hline Total & $11(18.33 \%)$ & $49(81.66 \%)$ & 60 \\
\hline \multicolumn{2}{|c|}{$\mathrm{X}^{2}=8.19 ;$ D.F. $=1 ; \mathrm{P}=6.64($ at 0.01$) ; \chi^{2}>\mathrm{P}($ at 0.01$)$}
\end{tabular}

Table 4: Classification of Redness at Umbilicus

\begin{tabular}{|c|c|c|c|}
\hline Group & e/o Redness & No e/o Redness & Total \\
\hline Trial & $4(13.33 \%)$ & $26(86.66 \%)$ & 30 \\
\hline Control & $15(50 \%)$ & $15(50 \%)$ & 30 \\
\hline Total & $19(31.66 \%)$ & $41(68.33 \%)$ & 60 \\
\hline \multicolumn{4}{|c|}{$\mathrm{X}^{2}=9.3 ;$ D.F. $=1 ; \mathrm{P}=6.64($ at 0.01$)$}
\end{tabular}

Table 6: Classification of pus discharge through Umbilicus

\begin{tabular}{|c|c|c|c|}
\hline Group & e/o pus discharge & $\begin{array}{c}\text { No e/o pus } \\
\text { discharge }\end{array}$ & Total \\
\hline Trial & 0 & $30(100 \%)$ & 30 \\
\hline Control & $4(13.33 \%)$ & $26(86.66 \%)$ & 30 \\
\hline Total & $4(6.66 \%)$ & $56(93.33 \%)$ & 60 \\
\hline \multicolumn{2}{|c|}{$\mathrm{X}^{2}=4.28 ; \mathrm{D} . \mathrm{F} .=1 ; \mathrm{P}=3.84$ (at 0.05$) ; \mathrm{X}^{2}>\mathrm{P}$ (at 0.05$)$}
\end{tabular}

Table 7: Classification of Duration to Shedding the Cord

\begin{tabular}{|c|c|c|c|c|c|c|c|}
\hline Group & $\mathbf{4}^{\text {th }}$ day & $\mathbf{5}^{\text {th }}$ & $\mathbf{6 t h}^{\text {9th }}$ & $\mathbf{7}^{\text {th }}$ & 8th & Total \\
\hline Trial & $5(16.66 \%)$ & $7(23.33 \%)$ & $10(33.33 \%)$ & $6(20 \%)$ & $2(6.66 \%)$ & 0 \\
\hline Control & $7(23.33 \%)$ & $5(16.66 \%)$ & $9(30 \%)$ & $2(6.66 \%)$ & $6(20 \%)$ & $1(3.33 \%)$ & 30 \\
\hline Total & 12 & 12 & 19 & 8 & 8 & 1 \\
\hline
\end{tabular}

Table 8: Gestational Age wise Nabhipaka

\begin{tabular}{|c|c|c|c|c|c|c|c|}
\hline \multirow[t]{2}{*}{ Group } & \multicolumn{5}{|c|}{ e/o s/o Nabhipaka } & \multirow{2}{*}{$\begin{array}{c}\text { No e/o s/o } \\
\text { Nabhipaka }\end{array}$} & \multirow[t]{2}{*}{ Total } \\
\hline & 35 weeks & 36 weeks & 37 weeks & 38 weeks & 39 weeks & & \\
\hline Trial & 0 & 0 & $4(13.33 \%)$ & $1(3.33 \%)$ & 0 & $25(83.33 \%)$ & 30 \\
\hline Control & $1(5.88 \%)$ & $1(5.88 \%)$ & $6(35.29 \%)$ & $6(35.29 \%)$ & $2(11.76 \%)$ & $14(46.66 \%)$ & 30 \\
\hline Total & 1 & 1 & 10 & 7 & 2 & 39 & 60 \\
\hline
\end{tabular}

Table 9: Findings of C-reactive protein

\begin{tabular}{|c|c|c|c|}
\hline Group & +ve & -ve & Total \\
\hline Trial & 00 & $30(100 \%)$ & 30 \\
\hline Control & $01(3.33 \%)$ & $29(96.66 \%)$ & 30 \\
\hline Total & 01 & 59 & 60 \\
\hline \multicolumn{2}{|c|}{$\mathrm{X}^{2}=1.016 ;$ D.F. $=1 ; \mathrm{P}=3.84($ at 0.05$) ; \chi^{2}<\mathrm{P}($ at 0.05$)$}
\end{tabular}

\section{RESULTS}

To evaluate the role of Haridradi Tailam in Nabhinal paricharya in the prevention of Nabhipaka it was necessary to note down the changes in the manifestations. These case records were interpreted into the results on the basis of observations which is summarized in Table 3 to Table 9. Table 3 shown that 5 patients $(16.66 \%)$ had developed signs of Nabhipaka and 25 patients $(83.33 \%)$ were free from signs of nabhipaka in trial group. In control group $17(56.66 \%)$ patients developed signs of nabhipaka and $13(43.33 \%)$ patients were free from signs of nabhipaka. Chi square value of these observations was 10.33 , which is significant. It indicates that treatment in trial group is effective in prevention of Nabhipaka.

Also Table 4 indicates four $(13.33 \%)$ patients had developed redness at umbilicus and $26(86.66 \%)$ patients were free from redness at umbilicus in trial group. In control group $15(50 \%)$ patients developed redness and 15 $(50 \%)$ patients were free from redness at umbilicus. Chi square value of these observations is 9.3, which is significant. It indicates that treatment in trial group is effective in prevention of redness at umbilicus. In this study $1(3.33 \%)$ patient had developed tenderness at umbilicus and $29(96.66 \%)$ patients were free from tenderness at umbilicus in the trial group. In control group $10(33.33 \%)$ patients were developed tenderness and 20 $(66.66 \%)$ patients were free from tenderness at umbilicus. Chi square value of this observation is 8.19 , which is significant. It indicates that the treatment in the trial group is effective in the prevention of tenderness at umbilicus as shown in Table 5. Throughout study not a single patient developed pus discharge through umbilicus in trial group. In control group $4(43.33 \%)$ patients developed pus discharge and $26(86.66 \%)$ patients were free from pus discharge through umbilicus. Chi square value of this observation is 4.28 , which is significant. Table 6 indicates that the treatment in the trial group is effective in the prevention of pus discharge through umbilicus. Table 7 illustrate that maximum $10(33.33 \%)$ patients required 6 days for the shedding of the umbilical cord in the trial group. In the control group maximum $9(30 \%)$ patients required 6 days for the shedding of the umbilical cord. Chi square value of these observations is 5.68 , which is insignificant. It indicates that treatment in the trial group is not related to duration taken for the shedding of cord. The difference in the values is natural. In this study 4 
$(13.33 \%)$ patients of 37 weeks Gestational age and 1 (3.33\%) patient of 38 weeks Gestational age developed signs of Nabhipaka in the trial group. $25(83.33 \%)$ patients were free from signs of Nabhipaka. In the control group $1(5.88 \%)$ patient of 35 weeks Gestational age, 1 (5.88\%) patient of 36 weeks Gestational Age, 6 (35.29\%) patients of 37 weeks Gestational age and 2 (11.76\%) patients of 39 weeks Gestational age developed signs of Nabhipaka. 14 (46.66\%) patients were free from signs of nabhipaka. Chi square value of observations is 11.56 , which is significant. It indicates that the gestational age is responsible for the Nabhipaka (Table 8). As per Table 9 Chi square value of observations is 1.016 , which is insignificant. It indicates the $\mathrm{C}$-reactive protein finding is natural.

\section{DISCUSSION}

Septicemia is one of the common pediatric problems. In neonates it is commonly developed through the root of umbilicus, which hampers the health of the child. Large numbers of patients of pathogenic infections are reported from the developing countries. It has become more common in society due to improper Nabhinal paricharya and certain unhygienic conditions of newborn like-

- Unsterilized instruments for the cutting of umbilical cord.

- Improper ligation of umbilical cord.

- Use of dirty clothes.

- Use of wet Napkins.

- Dirty and over handling of baby.

- Moisture at umbilicus.

In modern science many drugs are available in market for the treatment of local umbilical sepsis (Nabhipaka) and septicemia. These drugs benefit the patients temporarily, but likely to cause adverse effects on the children as allergic reactions and resistance to the drug action.

To find out the solution to these possibilities the preventive treatment of nabhipaka, Nabhinal paricharya according to Charak samhita is selected for the study. Haridradi tailam is applied on the umbilicus till the cord sheds, which is prepared from Haridra, priyangu, lodhra, yesthimadhu, deodara and til tailam.

Haridra is tikta, katu rasa, katu vipaka, ushna virya and laghu, ruksha guna and Tridoshahar, especially kaphashamak. It is shothahar, vedana-sthapak, kusthaghna and vranaropak, vranashodhak. It has blood purifier and antiseptic properties ${ }^{16}$.

Priyangu is tikta, kashaya, madhur rasa, katu vipaka, sheet virya, tridoshahar specially pittashamak. It acts as vedanasthapak, dahaprashamak, daurgandhanashak and twakdoshahar ${ }^{17}$.

Lodhra is kashaya rasa, katu vipaka, sheet virya and kaphapittashamak. It has various karmas like shothahar, kusthaghna, raktasthambak, sankochak and vranaropak ${ }^{18}$. Yesthimadhu is madhur rasa and vipak, sheet virya and vatapitta shamak, especially pittashamak. It acts as dahashamak, vedanasthapak and shothahar ${ }^{19}$.

Deodara has tikta rasa, katu vipaka and ushna virya. It acts as kaphavatashamak. Its various karmas like shothahar, vedanasthapak, krimighna. The main constituent of the tailam is a resquiterpene, which is associated with a resquiterpene alcohol ${ }^{20}$.

Til tailam is madhur,vipaka, ushna virya, tikshna, guru, sukshma, vyavyi, vikasi, sara, snigdha guna and tridoshashamak, vranaropak, vranashodhak and mansasthairyakar. It has best snehan and antioxidant property. It acts as lekhaniya, mardavkar, krimighna and sarvaroghar after sanskara ${ }^{21}$.

All these drugs are contents of Haridradi tailam, which is kledaghna, kaphaghna, shulaghna, shothaghna, raktastambhak, raktashodhak, vranashodhak and vranaropak. Hence it is very useful in local application to prevent and subside of associated symptoms like redness, swelling, tenderness at umbilicus and pus discharge through umbilicus.

For control group surgical spirit was applied to the cut cord only once i.e. at the time of cutting of the cord. No medication was applied to the cord till it sheds. So efforts were made to study the effects of Haridradi tailam in Nabhinal paricharya. Study was carried out in kaumarbhritya tantra Department of Govt. Ayurved College and Hospital, Nanded, Maharashtra, India.

Patients were examined thoroughly, investigated and treatment to both groups was given till the cord shaded off. Keen observations were kept regarding the symptoms of baby and pathya- apathya were advised regularly to the mother of both groups to avoid hetu sevana.

Among the parameters TLC, CRP investigations were done at the beginning and at the end of the treatment. If pus discharge through umbilicus occurs then gram staining of pus was done to rule out the infection and pathogenic organisms.

Here for the study of Nabhinal paricharya $40 \%$ male, $60 \%$ female patients were selected in trial group and 50\% male, $50 \%$ female patients were selected in the control group.

Signs of Nabhipaka occurred in $16.17 \%$ patients of trial group, among them $20 \%$ male and $80 \%$ female were affected, where as $56.66 \%$ patients had the signs of Nabhipaka in control group, among them 56.66\% male and $43.33 \%$ females were affected.

Redness at umbilicus occurred in $13.33 \%$ patients of the trial group and $50 \%$ patients of the control group. Tenderness at umbilicus occurred in 3.33\% patients of trial group and $33.33 \%$ patients of the control group. Swelling at umbilicus occurred in $3.33 \%$ patients of the trial group and $43.33 \%$ patients of control group. After the shedding off of umbilical cord $13.33 \%$ patients had umbilical pus discharge in control group, where as no umbilical pus discharge occurred in a single patient of the trial group. Study was done in all seasons. Signs of nabhipaka occurred $16.66 \%$ patients in summer, $14.28 \%$ patients in winter and $17.64 \%$ patients in rainy season of the trial group, where as $54.44 \%$ patients in summer, $50 \%$ patients in winter and $30 \%$ patients in rainy season of the control group.

Maximum patients (33.33\%) required 6 days for shedding off the umbilical cord of the trial group and $30 \%$ patients of the control group.

During the study of Haridradi Tailam adverse reaction was found in a single patient of the trial group as multiple 
boils were formed and red skin rashes were seen around the umbilicus.

In trial group $13.33 \%$ patients of 37 weeks gestational age developed more signs of nabhipaka. In the control group $35.29 \%$ patients of 35 weeks and 36 weeks gestational age developed more signs of babhipaka.

In perinatal period (during the treatment period) fever occurred more in patients of the trial group $(36.66 \%)$ compared to control group (26.66\%).

Signs of nabhipaka occurred more in patients of the trial group of birth weighing 2.5 to $3.5 \mathrm{~kg}$ and in patients of the control group of birth weighing 2.5 to $3 \mathrm{~kg}$. C-reactive protein is found significant $(+\mathrm{ve})$ in a single patient of the control group after shedding off the umbilical cord.

\section{CONCLUSION}

Haridradi tailam is very effective in Nabhinal paricharya in the prevention of nabhipaka. It resists completely the growth of infection from gram + ve Diplococci, gram + ve Bacilli, Klebsiella, pneumoniae etc. There was no pus discharge through the umbilicus after the Nabhinal paricharya in the trial group. Associated signs and symptoms were also minimum in the trial group compared to control group. Haridradi tailam is very effective due to its vranaropak, vranashodhak, shothaghna, shulaghna, raktashodhak and raktastambhak property.

\section{REFERENCES}

1. Paranjape GR, Ranade S. Ayurved Itihas, $4^{\text {th }}$ ed, Pune, India. Anmol publications 2002 p. 8

2. Tripathi R. editor, Hindi commentary, In Ashtanga Sangraha, Sutrasthana, reprint, chapter 1, verse 6, Delhi, India. Chaukhambha Surabharati Publication 2005 p 3

3. Tripathi B. editor, Hindi commentary, In Charak Samhita, reprint, Sutrasthana, chapter 1, verse 15, Varanasi, India. Chakhambha Surbharati publication, 2006 p 6

4. Tripathi B. editor, Hindi commentary, In Charak Samhita, reprint, Sutrasthana, chapter 30, verse 26, Varanasi, India. Chakhambha Surbharati publication 2006 p 565
5. Tripathi B. editor, Hindi commentary, In Charak Samhita, reprint, Sharirasthana, chapter 8 , verse 44 , Varanasi, India. Chakhambha Surbharati publication 2006 p 966

6. Ghai OP, Gupta P, Paul VK. Essential pediatrics, $6^{\text {th }}$ ed, New Delhi, India. CBC publications 2004 p. 163-64

7. Singh M. Care of the newborn, $6^{\text {th }}$ ed, New Delhi, India. Sagar publications 2004 p 396.

8. Vishwanathan J, Desai AB. Editor, Achar's textbook of pediatrics, $3^{\text {rd }}$ ed, Chennai, India. Orient Laongman publication 2000 p 407

9. Tripathi KD. Essentials of medical pharmacology, $6^{\text {th }}$ ed, Delhi, India. Jaypee brother's medical publications 2008 p 381.

10. Tripathi B. editor, Hindi commentary, In Charak Samhita, reprint, Sharirasthana, chapter 8 , verse 44 , Varanasi, India. Chakhambha Surbharati publication 2006 p 966

11. Sharma P. hindi Commentary, Sharangadhara Samhita, $7^{\text {th }}$ ed, Purva khanda, verse 48, Varanasi, India. Chaukhambha Amarabharati publications $1988 \mathrm{p} 14$

12. Sharma P. Hindi Commentary, Sharangadhara Samhita, Purva khanda, chapter 9, verse 1, $7^{\text {th }}$ edition, Varanasi, India. Chaukhambha Amarabharati publications 1988 p 220

13. Singh M. Care of the newborn, $6^{\text {th }}$ ed, New Delhi, India. Sagar publications 2004 p 133

14. Richard EB, Robert MK, Hal BJ. Nelson textbook of pediatrics, $17^{\text {th }}$ ed, India, Elsevier publications 2006 p 726

15. Ritchie AC. Boyd's textbook of pathology, part $1,9^{\text {th }}$ ed, Beckenham, UK, Lea and Febiger publications 1990 p 103

16. Sharma PV. Dravyaguna Vijnyana part 2, reprint, Varanasi India, Chaukhambha Bharati Academy 2005 p 163

17. Sharma PV. Dravyaguna Vijnyana part 2, reprint, Varanasi India, Chaukhambha Bharati Academy 2005 p 782

18. Sharma PV. Dravyaguna Vijnyana part 2, reprint, Varanasi India, Chaukhambha Bharati Academy 2005 p 616

19. Sharma PV. Dravyaguna Vijnyana part 2, reprint, Varanasi India, Chaukhambha Bharati Academy 2005 p 254

20. Sharma PV. Dravyaguna Vijnyana part 2, reprint, Varanasi India, Chaukhambha Bharati Academy 2005 p 76

21. Sharma PV. Dravyaguna Vijnyana part 2, reprint, Varanasi India, Chaukhambha Bharati Academy 2005 p 121

\section{Cite this article as:}

Raut D. W., Chavan D. B.. Role of Haridradi tailam application in prevention of Nabhi paka (umbilical sepsis) in neonates. Int. J. Res. Ayurveda Pharm. 2013;4(3):382-386 